\title{
Keluarga Islami sebagai Basis Pendidikan Dasar Anak
}

\author{
Akhmad Yusron \\ Staf Pengajar Program Studi PGMI UNISDA Lamongan \\ Yusronakhmad03@gmail.com
}

\begin{abstract}
Abstrak
Orang tua merupakan pemegang amanah dalam memberikan kebutuhan biologis, merawat, dan memberikan pendidikan. Lingkungan keluarga punya peranan penting dalam pendidikan anak dititikberatkan pada curahan kasih sayang yang mengiringi proses pendidikan.

Dimensi praktis pendidikan Islam memerlukan pengawasan yang optimal yang dapat diberikan oleh orang tua dalam lingkungan kelurga. Keluarga Islami melalui implementasi Living Sunnah dan dioptimalkan dengan beberapa metode, seperti; keteladanan, Pembiasaan, Hukuman, dan Nasehat.

Metode Pembiasaan dapat dilakukan oleh keluarga Islami melalui perintah menutup aurat, salat berjamaah lima waktu, dan sebagainya. Implementasi metode Pembiasaan, metode Nasehat harus terintegrasi dengan metode Keteladanan.
\end{abstract}

Kata kunci: Pendidikan anak, Keluarga Islami, Living Sunnah

\section{Pendahuluan}

Dalam pemberitaan yang masih hangat di televisi menyebutkan kasus pembunuhan yang dilakukan oleh ibu kandung yang membunuh anaknya dengan menggunakan gunting dan semprotan nyamuk karena alasan sering ngompol dan menangis. ${ }^{1}$ Berita kriminalitas yang dilakukan oleh seorang ibu terhadap anak semacam ini, bukanlah terjadi pertama kali. Sungguh ironis, bila mencermati peran ibu yang seharusnya merupakan pilar utama dalam keberhasilan pendidikan anak, justru malah sebaliknya.

Tidak dipungkiri kekerasan dalam rumah tangga yang pelakunya adalah ibu kandung sendiri, umumnya dilatarbelakangi masalah keluarga. Karena faktor himpitan ekonomi, broken home, single parent menjadikan sosok wanita yang memiliki naluri keibuan tega untuk berbuat sadis terhadap anaknya.

Hal ini menjadi sebuah keprihatinan tersendiri bagi para calon mempelai yang hendak membina keluarga, untuk kembali merenungkan "niat nikah".

\footnotetext{
${ }^{1}$ Diskusi tentang "Pembunuhan Sang Ibu terhadap anaknya" yang disiarkan dalam Program Televisi Talk to News, TV One, tgl 13 November 2017, jam 07.50 WIB
} 
Sebagai umat dari agama yang sangat menjunjung tinggi cinta dan kasih sayang, Umat Islam perlu merenungkan hakikat tujuan menikah yang dibenarkan syariat sebelum melangsungkan pernikahan. Pernikahan harus dipersiapkan dengan matang, terkait urusan yang dibutuhkan saat pernikahan dan setelahnya, mulai dari segi materiil sampai pengetahuan yang mendasar dalam masalah Akidah, Fikih, dan etika berkeluarga. Dengan kesiapan inilah diharapkan mampu mencetak keluarga yang Islami.

Keluarga Islami adalah sebuah bentuk keluarga yang berusaha menerapkan ajaran Rasulullah Saw. Mengingat beliau selalu mengajarkan sikap berakhlak baik kepada keluarga. Keluarga Islami bukanlah hanya menitikberatkan pada status agama dari anggota-anggota keluarga. Dapat dikatakan embel-embel "Islami" menandaskan bahwa keluarga yang bersangkutan membudayakan sunnah yang diajarkan Rasulullah Saw. di setiap harinya.

Berdasar alasan inilah, penulis merasa tertarik untuk mengkaji lebih jauh konsep keluarga Islami sebagai basis dari pendidikan anak. Agar lebih fokus, peneliti membatasi objek kajian terkait anak pada rentang usia MI (7-13 tahun).

\section{Pembahasan}

Dalam ajaran Islam, sarana untuk membentuk keluarga dimulai dari ikatan pernikahan. Gerbang berdirinya keluarga ini menjadi perhatian khusus dalam ajaran Islam, baik dari segi hukum yang dibahas dalam pokok bahasan Fikih berupa "Kitab an-Nikah" maupun dari segi Akhlak yang menjelaskan makna “Mu'asyarah bi al-Ma'ruf wa Huquq al-Zaujain". Dengan melangsungkan pernikahan, maka pasangan suami istri akan memperoleh manfaat dari pernikahan tersebut. Salah satu manfaatnya adalah memelihara kelangsungan hidup manusia di dunia melalui keturunan. Kelahiran anak merupakan amanat dari Allah Swt kepada orangtua. Tanggungjawab orangtua sebagai pemegang amanat ini adalah mencukupi kebutuhan biologis, merawat, dan memberikan pendidikan. Hal ini didasarkan pada firman Allah Swt. dalam surat At-Tahrim ayat 6 yang berbunyi:

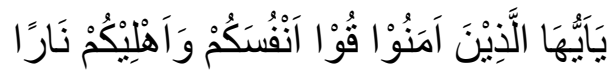




\title{
Artinya : "Hai orang-orang yang beriman, jagalah dirimu dan keluargamu
}

\author{
dari api neraka.....".
}

Anak dilahirkan tidak dalam keadan lengkap dan tidak pula dalam keadaan kosong. Ia dilahirkan dalam keadaan fitrah. Memang ia dilahirkan dalam keadaan tidak tahu apa-apa, akan tetapi anak telah dibekali dengan pendengaran, penglihatan, dan kata hati. ${ }^{3}$ Dengan diberikannya penglihatan, pendengaran, dan kata hati tersebut, diharapkan orang tua harus mampu membimbing, mengarahkan, dan mendidiknya dengan ekstra hati-hati karena anak sebagai peniru yang ulung.

'Amr bin Atabah dalam nasehatnya, -sebagaimana yang telah dikutip oleh Umar Hasyim- menyatakan sebagai berikut:

"Hendaklah tuntunan kebaikan yang pertama bagi anak-anakmu, dimulai dari perbaikan anda terhadap diri anda sendiri. Karena mata dan perhatian mereka selalu terikat pada anda. Mereka menganggap baik segala yang anda kerjakan, dan mereka menganggap jelek segala yang anda jauhi”.

Oleh karena itu orang tua dituntut semaksimal mungkin memberikan pelayanan terhadap anaknya. Pelayanan yang maksimal akan menghasilkan suatu harapan bagi bapak ibunya, tiada lain suatu kebahagiaan hasil jerih payahnya. Sebab anak adalah sumber kebahagiaan, kesenangan, dan sebagai harapan dimasa yang akan datang. ${ }^{4}$ Harapan-harapan orang tua akan terwujud, tatkala mereka mempersiapkan sedini mungkin pendidikan yang baik sebagai sarana pertumbuhan dan perkembangan bagi anak.

Untuk dapat mengatur rumah tangga agar berjalan baik, sakinah, dan mawaddah merupakan hal yang amat sulit. Orang tua harus siap untuk memadukan sekian banyak unsur dan dimensi mulai dari dimensi sikap mental, ilmu pengetahuan, ketrampilan dan lain sebagainya. Sebagai kewajiban dari orang

${ }^{2}$ Al-Qur'an, Surat At-Tahrim Ayat 6, Yayasan Penyelenggara Penterjemah/ Penafsir AlQur'an, Al-Qur'an dan Terjemahnya, Departemen Agama RI, 1989, hal. 951.

${ }^{3}$ Muhammad "Ali Quthb, Auladuna fi-Dlaw-it Tarbiyyatil Islamiyah, Terj. Bahrun Abu Bakar Ihsan, "Sang Anak dalam Naungan Pendidikan Islam", Bandung : Diponegoro, Cetakan II, 1993, hlm. 11.

${ }^{4}$ Muhammad Ali al-Hasyimi, The Ideal Muslimah the True Islamic Personality of The Muslim Woman as Defined in The Qur'an and sunnah, Terj. Fungky Kusnaedi Timur, "Muslimah Ideal pribadi Islami dalam al-Qur'an dan as-Sunnah", Yogyakarta : Mitra Pustaka, Cetakan I, 2000, hlm. 250-251. 
tua, dalam hal ini adalah pemegang amanat, maka barangsiapa yang mampu menjaga amanat tersebut akan diberi pahala, begitu pula sebaliknya.

Selain anak mampu menjadi penyejuk mata, keberadaan anak juga dapat menjadi fitnah bagi ayah dan ibunya. Sebagaimana Allah menjelaskan dalam firman-Nya;

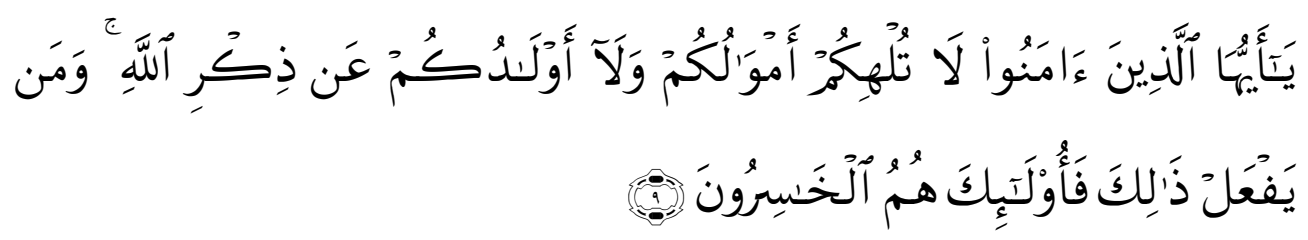

Artinya: "Hai orang-orang beriman, janganlah hartamu dan anak-anakmu melalaikan kamu dari mengingat Allah. Barangsiapa yang berbuat demikian Maka mereka Itulah orang-orang yang merugi” (QS. AlMunafiqun: 9)

Minimnya pendidikan agama tidak hanya berdampak pada anak yang dapat menjadi fitnah, bahkan anak bisa menjadi musuh bagi orang tuanya. Allah Swt. berfirman;

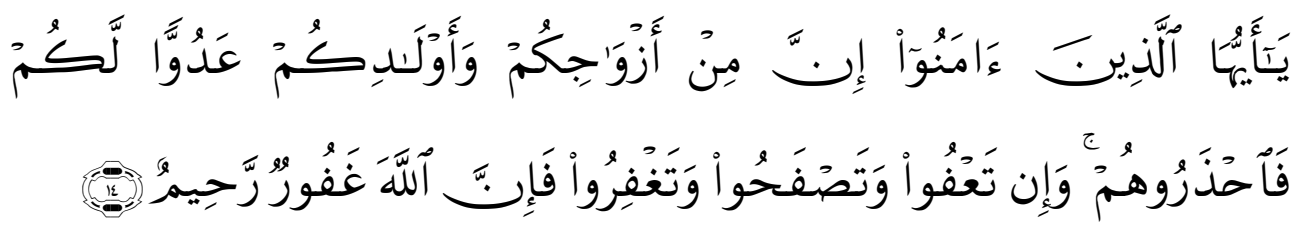

Artinya: "Hai orang-orang mukmin, Sesungguhnya di antara isteri-isterimu dan anak-anakmu ada yang menjadi musuh bagimu. Maka berhati-hatilah kamu terhadap mereka dan jika kamu memaafkan dan tidak memarahi serta mengampuni (mereka) Maka Sesungguhnya Allah Maha Pengampun lagi Maha Penyayang" (QS. At-Taghabun: 14)

Dalam mendidik anak, tentunya harus ada kesepakatan antara ayah dan ibu sebagai orang tua, akan dibawa kepada pendidikan yang otoriter atau pendidikan yang demokratis atau bahkan yang liberal, sebab mereka penentu pelaksana dalam keluarga.

Dalam kehidupan masyarakat terkecil, yaitu keluarga, suami secara fungsional adalah penanggung jawab utama rumah tangga (keluarga) sedangkan istri adalah mitra setia yang aktif konstruktif mengelola rumah tangga. Operasionalisasi kehidupan berkeluarga sebaiknya dilakukan berdasarkan Amar 
ma'ruf nahi munkar (memerintahkan kebaikan dan menjauhi kemaksiatan). Salah satu wujud Amar makruf nahi munkar bagi orang tua adalah memberikan pendidikan kepada putra-putrinya berdasarkan ajaran Islam.

Amanah pendidikan anak bagi orang tua dalam konsep Islam adalah memperkuat dan memperkokoh Akidah. Menurut Masyhuda al-Mawwaz, Akidah dapat tumbuh dengan baik dalam diri anak, apabila mereka disibukkan dengan membaca Al-Qur'an, mempelajari dan memahami Tafsir, membaca dan mengenalkan kandungan makna di dalamnya, serta melatih anak untuk aktif dalam aktivitas ibadah. ${ }^{5}$

Berdasar pernyataan Masyhuda al-Mawwaz di atas, dirasa sangat sulit diterapkan oleh orang tua pada saat ini. Orang tua sibuk mengurusi kecukupan kebutuhan jasmaniah dan mengamanahkan urusan kecukupan kebutuhan Ruhiyah kepada lembaga pendidikan Islam. Orang tua tidak boleh lepas dari pengontrolan masalah kebutuhan Ruhiyah. Meskipun secara teoritis diajarkan dalam lembaga pendidikan Islam, namun dalam permasalahan praktis yang sebenarnya harus banyak dipantau di lingkungan keluarga.

Setiap orang tua mempunyai prinsip dan sistem sendiri-sendiri dalam mendidik anaknya. Orang tua dapat meneladani prinsip pendidikan anak yang telah dicontohkan Rasulullah Saw. Beliau tidak pernah mendidik putra-putrinya dengan pendidikan keras dan tidak dengan membebaskan anak-anaknya, tetapi beliau dalam mendidik keluarganya terutama kepada anak-anaknya adalah dengan limpahan kasih sayang yang amat besar. ${ }^{6}$ Senada dengan yang dikatakan oleh sahabat Anas Ra. yaitu "Aku tidak mendapatkan seseorang yang kasih sayangnya pada keluarganya melebihi Rasulullah Saw."

Dalam mendidik anak harus mengenal karakteristik anak berdasar usia agar cara atau metode pendidikan yang ingin diterapkan dapat optimal dan efektif. Anak yang mengenyam pendidikan di tingkat madrasah Ibtidaiyah, umumnya berusia antara antara 7 sampai 13 tahun. Dalam beberapa kasus, terkadang ada juga peserta didik masuk MI berusia 6 tahun.

\footnotetext{
${ }^{5}$ Masyhuda al-Mawwaz, Mengantar Anak ke Surga (Surabaya: Edutama Mulia, 2010), hlm.89

${ }^{6}$ Aziz Mushoffa dan Imam Musbikin, Sepasang Burung dan Nabi Sulaiman, Yogyakarta: Mitra Pustaka, Cetakan I, 2001, hlm. V.

${ }^{7}$ Ibid., hlm. VI.
} 
Pada masa usia sekolah dasar, anak mulai membuka diri menjalin pertemanan dengan teman sebayanya. Fungsi keluarga pada rentang usia ini adalah memberikan bimbingan dan pengawasan. Sebagaimana Sahabat Ali bin Abi Thalib pernah mengemukakan bahwa ada tiga pengelompokkan dalam kaitannya memperlakukan anak. Pertama, kelompok 7 tahun awal (0-7 tahun), anak diperlakukan layaknya seorang raja. Kedua, kelompok 7 tahun kedua (8-14 tahun), anak diperlakukan layaknya seorang tawanan. Ketiga, kelompok 7 terakhir (15-21 tahun), anak diperlakukan layaknya sahabat. Maka tidak jarang para guru kelas 1 pada jenjang madrasah Ibtidaiyah, mengeluhkan perilaku bawaan anak TK yang cenderung manja, seperti mau masuk ke kelas apabila ditunggu ibunya.

Dalam posisi ini, peran pendidik di lembaga formal dibutuhkan untuk membantu orang tua mengkondisikan tahapan perkembangan anak agar lebih dewasa. Meskipun demikian, waktu bersama keluarga tetaplah dominan. Ada waktu untuk bersosial dan ada waktu untuk menata batin anak melalui keluarga.

Rasulullah Saw. dalam hadisnya, pernah bersabda;

"Perintahkan kepada anak untuk (mengerjakan) salat ketika sampai usia tujuh tahun dan ketika sampai usia 10 tahun (belum mengerjakan salat) maka pukullah dia (agar mau) untuk salat". 8

Seorang muslim sepatutnya mencontoh teladan yang telah diberikan Rasulullah Saw. dalam memuliakan putra putrinya. Beliau dalam mendidik para buah hati beliau melalui ajaran wahyu Ilahi yaitu dengan penuh kasih sayang terhadap anak-anaknya. Dengan pemberian kasih sayang tersebut, diharapkan dapat menunjang pertumbuhan dan perkembangan anak. Sebab anak merupakan aset masa depan. Sebagai orang tua dapat meneladani ajaran-ajaran Rasul SAW tersebut, melalui para pemikir dan pemerhati pendidikan (anak) dalam Islam.

Pendidikan moral anak dapat efektif jika terpenuhi faktor-faktornya. Salah satu factor tersebut adalah metode. Metode merupakan sarana untuk menyampaikan isi atau materi pendidikan, agar tujuan yang diharapkan dapat tercapai dengan hasil yang baik.

Lingkungan keluarga berperan aktif dalam menyukseskan pendidikan anak dan merupakan wadah penting dalam pendidikan anak karena lingkungan ini yang

\footnotetext{
${ }^{8}$ HR. Abu Dawud.
} 
paling diharapkan dapat memunculkan kasih sayang yang tulus. Sehingga pendidikan yang disertai dengan ketulusan hati, akan memberikan hasil yang lebih optimal. Hal ini dapat diteladani dari tarbiyah Allah Swt. terhadap umat manusia. Allah Swt. dalam mendidik umat manusia dengan penuh kasih sayang dan Ihsan (berbuat baik). Allah Swt. mempunyai sifat Maha Pengasih dan penyayang, dimana manusia menjalankan perintah-Nya untuk mendapatkan Ridha. ${ }^{9}$

Dalam proses pendidikan berbasis keluarga ini dapat ditempuh melalui beberapa metode. Sebagaimana yang dikemukakan oleh Nasikh Ulwan bahwa pendidikan anak dapat dilaksanakan melalui beberapa metode, seperti; keteladanan, Pembiasaan, Nasehat. ${ }^{10}$

Berikut ulasan lebih lanjut terkait dari metode-metode tersebut.

1. Pendidikan melalui keteladanan

Menurut al-Ghazali, anak adalah amanat bagi orang tuanya. Hatinya yang suci merupakan permata tak ternilai harganya, masih murni dan belum terbentuk. ${ }^{11}$ Orang tua sebagai pemegang amanah yang berkewajiban membentuk kepribadian anak. Sebelum mendidik orang lain, sebaiknya orang tua harus mendidik pada dirinya terlebih dahulu. Sebab anak merupakan peniru ulung. Segala informasi yang masuk pada diri anak, baik melalui penglihatan dan pendengaran dari orang di sekitarnya, termasuk orang tua akan membentuk karakter anak tersebut. Rasa imitasi dari anak yang begitu besar, sebaiknya membuat orang tua harus ekstra hati-hati dalam bertingkah laku, apalagi didepan anak-anaknya. Karena setiap perbuatan orangtua akan ditiru oleh anaknya.

Tidak mengherankan ketika kelakuan orangtua tidak terpuji, rasa keseganan anak terhadapnya akan memudar. Mengingat anak usia 7-13 tahun umumnya sudah Tamyiz (mampu membedakan hal yang baik dan buruk). Ketika anak tidak lagi segan kepada orangtuanya, anak tidak lagi takut kepada orangtua atau pura-pura takut ketika mau dihukum. Sehingga ketika orang lain memergoki anak berbuat nakal, anak tidak merasa takut ketika diancam mau

${ }^{9}$ Masyhuda al-Mawwaz, Mengantar Anak..., hlm. 70

${ }^{10}$ Abdullah Nashih Ulwan, Tarbiyah..., jilid II, t.th, hlm. 2.

${ }^{11}$ Haya Binti Mubarok al-Barik, Mausu'ah al-Mar'atul Muslimah, terj. Amir Hamzah Fachrudin, "Ensiklopedi Wanita Muslimah", Jakarta : Darul Falah, Cet. IV, 1998, hlm. 247. 
diadukan kepada orang tuanya. Bahkan pada puncaknya perilaku kenakalan anak bisa lebih buruk daripada apa yang diperbuat orang tuanya, karena sudah tidak ada lagi sosok panutan terdekat bagi anak. Sebaliknya bila orangtua disegani karena akhlak mulianya, anak akan merasa sangat takut apabila berbuat nakal dan diancam untuk diadukan ke orangtuanya.

Al-Ghazali -sebagaimana yang dikemukakan oleh Masyhuda alMawwaz- menjelaskan terkait bimbingan moral yang layak diterima oleh anak sebagai berikut; ${ }^{12}$

“Anak adalah amanah bagi kedua orang tuanya. Hatinya yang suci tidak ubahnya mutiara mahal yang masih polos dan belum terukir apapun serta menerima dengan mudah segala model ukiran. Hatinya pun mudah terbawa dan mengikuti kemana ia diarahkan. Karena itu jika anak dibiasakan dan diberi bimbingan akan kebaikan maka ia pasti tumbuh bersama kebaikan tersebut. Sebaliknya jika anak dikondisikan dengan suasana buruk serta dibiarkan tidak diberi pengarahan maka kelak anak pasti celaka dan sengsara. Tentu saja dosa akan membelit leher orang yang bertanggungjawab atasnya. Jagalah anak dengan memberikan bimbingan dan pemahaman tentang akhlak mulia”.

Sebuah peribahasa terkenal "Buah jatuh tidak jauh dari pohonnya" merupakan sebuah rekam pengalaman orang terdahulu yang membuktikan bahwa perilaku anak duturunkan dari perilaku orangtuanya. Mitos orang Jawa bahkan mengemukakan bahwa perilaku tercela yang dilakukan orangtua akan dibalas dengan perilaku tercela yang dilakukan anak.. Oleh karena itu sudah sepantasnya bagi orang tua pemegang amanat, untuk memberikan teladan yang baik kepada putra putrinya dalam kehidupan berkeluarga.

Keluarga merupakan "Madrasah al-Ula" (sekolah pertama) bagi anak. Orang tua terutama ibu merupakan pendidik pertama dan utama bagi anak dalam membentuk pribadinya. Ibu mempengaruhi anak melalui sifatnya yang menghangatkan, menumbuhkan rasa diterima, dan menanamkan rasa aman pada diri anak. Sedangkan ayah mempengaruhi anaknya melalui sifatnya yang mengembangkan kepribadian, menanamkan disiplin, memberikan arah dan

${ }^{12}$ Masyhuda al-Mawwaz, Mengantar Anak..., hlm. 111 
dorongan serta bimbingan agar anak tambah berani dalam menghadapi kehidupan. $^{13}$

Teladan yang baik dari orang tua kepada anak (sekitar umur 6 tahun) akan berpengaruh besar kepada perkembangan anak di masa mendatang. Sebab kebaikan di waktu kanak-kanak awal menjadi dasar untuk pengembangan di masa dewasa kelak. Untuk itu lingkungan keluarga harus sebanyak mungkin memberikan keteladanan bagi anak. Dengan keteladanan akan memudahkan anak untuk menirunya. Sebab keteladanan lebih cepat mempengaruhi tingkah laku anak. Sesuatu yang dilihat oleh anak, akan ditirukan dan lama kelamaan akan menjadi kebiasaan bagi anak. Sebagaimana Rasulullah Saw. memberikan teladan kepada umatnya dan ditirukan oleh para sahabat sampai menjadi tradisi yang berkembang di kota Madinah. Kebanyakan pengajaran yang diberikan Rasulullah Saw. dapat diamati dari apa yang beliau tindakan. Ketika beliau memerintahkan sesuatu terhadap umatnya, beliau terlebih dahulu menindakannya. ${ }^{14}$

Dalam hal keteladanan ini, lebih jauh Abdullah Nashih Ulwan menafsirkan dalam beberapa bentuk, yakni; keteladanan dalam ibadah, bermurah hati, kerendahan hati, kesantunan., keberanian, dan memegang Akidah. $^{15}$

Mengingat obyeknya anak usia dini, tentunya bagi orang tua dalam memberikan teladan harus sesuai dengan perkembangannya sehingga anak mudah mencerna apa yang disampaikan oleh bapak dan ibunya. Sebagai contoh agar anak membiasakan diri dengan ucapan "salam”, maka senantiasa orang tua harus memberikan ajaran tersebut setiap hari yaitu hendak pergi dan pulang ke rumah (keteladanan kerendahan hati).

Orang tua juga harus memberikan keteladanan bertuturkata yang baik. Pertengkaran antara ayah dan ibu tidak sepantasnya diperlihatkan di hadapan anak. Seorang anak yang sering mendengar pertengkaran antara ayah dan ibunya, menjadikan beban psikologis dan menjadikannya sebagai pribadi

\footnotetext{
${ }^{13}$ Abdurrahman 'Isawi, Anak dalam Keluarga, Jakarta : Studia Press, Edisi II, 1994, hlm. 35.

${ }^{14}$ Abd al-Fattah Abu Ghuddah, Ar-Rasul al-Mu'alim wa asaliibihi fi at-Ta'lim (Maktabah Al-Manba', t.th), hlm.

${ }^{15}$ Abdullah Nashih Ulwan, Tarbiyah..., Jilid II, t.th, hlm. 6.
} 
mudah murung. Untuk itulah penting bagi orang tua tampil dihadapan anak sesuai dengan ajaran-ajaran Islam, niscaya semua itu akan ditirunya.

2. Pendidikan dengan pembiasaan

Setiap manusia yang dilahirkan membawa potensi, salah satunya berupa potensi beragama. Potensi beragama ini dapat terbentuk pada diri anak (manusia) melalui 2 faktor, yaitu: faktor pendidikan Islam dan faktor pendidikan lingkungan yang baik. Faktor pendidikan Islam yang bertanggung jawab penuh adalah ayah dan ibunya. Ia merupakan pembentuk karakter anak. Hal ini sesuai dengan sabda Rasulullah Saw. yang diriwayatkan oleh Sahabat Abu Hurairah Ra.;

"Tidak ada anak yang dilahirkan, kecuali dalam keadaan fitrah. Maka kedua orang tuanyalah yang akan menjadikannya sebagai orang Yahudi, Nasrani, atau Majusi". ${ }^{16}$

Setelah anak diberikan masalah pengajaran agama sebagai sarana teoritis dari orang tuanya, maka faktor lingkungan harus menunjang terhadap pengajaran tersebut, yakni orang tua senantiasa memberikan aplikasi pembiasaan ajaran agama dalam lingkungan keluarganya. Sebab pembiasaan merupakan upaya praktis, pembentukan (pembinaan) dan persiapan. ${ }^{17}$

Pada umur kanak-kanak kecenderungannya adalah meniru apa yang dilakukan oleh orang-orang di sekitarnya, baik saudara famili terdekatnya ataupun bapak ibunya. Oleh karena itu patut menjadi perhatian semua pihak, terutama orang tuanya selaku figur yang terbaik di mata anaknya. Jika orang tua menginginkan putra-putrinya tumbuh dengan menyandang kebiasaankebiasaan yang baik dan akhlak terpuji serta kepribadian yang sesuai ajaran Islam, maka orang tua harus mendidiknya sedini mungkin dengan moral yang baik. Karena tiada yang lebih utama dari pemberian orang tua kecuali budi pekerti yang baik. Hal ini sesuai dengan sabda Rasulullah Saw. yang diriwayatkan oleh Ayyub bin Musa; "Diceritakan dari Ayyub bin Musa dari ayahnya dari kakeknya, bahwa Rasulullah saw bersabda: Tidak ada

\footnotetext{
${ }^{16}$ Muslim bin Hajjaj, Shahih Muslim, juz IV, Lebanon : Dar al-Kutbi al-Ilmiah, t.th, hlm. 2047.

${ }^{17}$ Abdullah Nashih Ulwan, Tarbiyah ..., hlm. 59.
} 
pemberian yang lebih utama dari seorang ayah kepada anaknya kecuali budi pekerti yang baik". ${ }^{18}$

Apabila anak dalam lahan yang baik (keluarganya) memperoleh bimbingan, arahan, dan adanya saling menyayangi antar anggota keluarga, niscaya lambat laun anak akan terpengaruh informasi yang ia lihat dan ia dengar dari semua perilaku orang-orang di sekitarnya. Pengawasan dari orang tua sangat diperlukan sebagai kontrol atas kekeliruan dari perilaku anak yang tak sesuai dengan ajaran Islam.

Living Sunnah (menghidupkan Sunnah dalam kehidupan sehari-hari) merupakan indikator bagi sebuah komunitas kecil yang terbentuk melalui ikatan pernikahan yang disebut sebagai "keluarga Islami". Sunnah adalah segala bentuk tradisi baik yang telah diajarkan Rasulullah Saw. untuk dapat diteladani dan ditindakan oleh umat Islam. ${ }^{19}$

Apabila Living Sunnah dipahami sebagai upaya mengamalkan dan meneladani segala bentuk perbuatan yang dilakukan oleh Rasulullah Saw., maka sangat sulit untuk dipenuhi. Living Sunnah yang dimaksud di sini adalah mengawali untuk tidak melaksanakan perbuatan maksiat dan melaksanakan kewajiban yang ditunjang dengan perbuatan yang dianjurkan Rasulullah Saw. sesuai dengan kadar kemampuan. Sebagaimana ditegaskan dalam hadis yang diriwayatkan oleh Sahabat Abu Hurairah Ra. bahwa Rasulullah Saw. bersabda: “Apa yang telah aku larang kepada kamu sekalian maka jauhilah dan apa yang telah aku perintahkan kepada kamu sekalian maka lakukanlah......, ${ }^{20}$

Hal yang terpenting dalam menjalankan perbuatan yang dianjurkan Rasulullah Saw. adalah konsistensinya. Seperti yang telah dijelaskan oleh Rasulullah Saw.: "Sebaik-baiknya amal perbuatan adalah yang paling konsisten meski sedikit." 21

Perbuatan wajib yang harus diteladankan oleh orang tua serta harus dilatihkan dan dibiasakan adalah menggunakan pakaian yang menutup aurat, hlm. 298.

${ }^{18}$ At-Tirmidzi Muhammad bin Isa, Sunan At-Tirmidzi, Lebanon : Dar al-Kutbi, Juz IV, t.th,

${ }^{19}$ HR. At-Turmudzi

${ }^{20}$ HR. Muslim 
terlebih pada anak perempuan. Sebagaimana Allah Swt. menegaskan dalam firman-Nya;

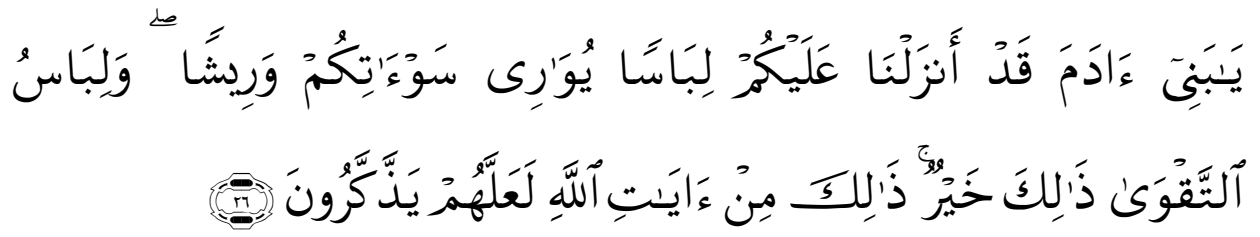

Artinya: "Hai anak Adam, Sesungguhnya Kami telah menurunkan kepadamu pakaian untuk menutup auratmu dan pakaian indah untuk perhiasan. dan pakaian takwa Itulah yang paling baik. yang demikian itu adalah sebahagian dari tanda-tanda kekuasaan Allah, Mudah-mudahan mereka selalu ingat".

Perintah shalat pada umur 7 tahun sejatinya adalah perintah secara umum kepada hal-hal yang diwajibkan syariat, termasuk menutup aurat. Pembiasaan lain yang dapat dilakukan orang tua kepada putra-putrinya adalah anjuran untuk menunaikan shalat secara berjamaah. Gambaran sederhana ketika membiasakan tradisi shalat berjamaah akan membentuk watak disiplin anak. Mengingat tradisi berjamaah tidaklah mungkin dilakukan pada penghujung waktu shalat. Lebih-lebih dengan shalat berjamaah terdapat kontak komunikasi yang luar biasa, anggota keluarga bisa mengamini doa pemimpin keluarga yang mana doa itu ditujukan untuk kebaikan seluruh anggota keluarga itu sendiri. Tradisi berjabat tangan setelah shalat berjamaah, mempererat ikatan batin yang harmonis antar sesama anggota keluarga. Metode Pembiasaan tidak dapat berdiri sendiri, melainkan harus terintegrasi dengan metode lainnya, yakni metode keteladanan.

3. Pendidikan dengan Nasehat

Nasehat idealnya diberikan oleh orang yang berwibawa menurut objek yang diberi nasehat. Dalam konteks keluarga Islami, pemberi nasehat yang paling ideal adalah orang tuanya sendiri selaku pemegang amanah pendidikan anak. Anak akan mendengarkan nasehat tersebut, apabila pemberi nasehat juga bisa memberi keteladanan. Sebab nasehat saja tidak cukup bila tidak diikuti dengan keteladanan yang baik. 
Anak akan melaksanakan nasehat tersebut apabila didapatinya pemberi nasehat tersebut juga melaksanakannya. Anak tidak butuh ucapan teoritis saja, melainkan pelaksanaan praktis yang akan mampu memberikan pengaruh bagi diri anak.

Nasehat yang berpengaruh, membuka jalannya ke dalam jiwa secara langsung melalui perasaan. Setiap manusia (anak) selalu membutuhkan nasehat, sebab dalam jiwa terdapat pembawaan itu biasanya tidak tetap, dan oleh karena itu kata-kata atau nasehat harus diulang-ulang. ${ }^{22}$

Hati manusia selalu berbolak-balik, terkadang pada suatu waktu condong kepada kebaikan dan di waktu lain berbalik kepada keburukan. Ketika keimanan menipis dan semangat untuk melaksanakan kebaikan menurun inilah nasehat amat diperlukan. Sebagaimana dalam Hadis riwayat Sahabat Abu Sa'id al-Khudri dijelaskan;

"Barangsiapa yang melihat kemungkaran diantara kamu maka ubahlah dengan kekuasaannya, jika tidak mampu maka dengan lisannya, jika tidak mampu maka dengan hatinya, dan ini adalah selemah-lemahnya iman”. (HR. Muslim)

Dari bunyi hadis di atas, mengubah kemungkaran dapat menggunakan metode nasehat. Untuk posisi ini dapat dilakukan oleh orang yang disegani bagi pelaku kemaksiatan. Jika anak nakal, maka nasehat lebih utama diberikan oleh orangtua yang biasanya disegani oleh anak.

Nasehat akan berhasil atau mempengaruhi jiwa anak, tatkala orangtua mampu memberikan keadaan yang baik. Hal ini sesuai dengan firman Allah Swt. yang berbunyi;

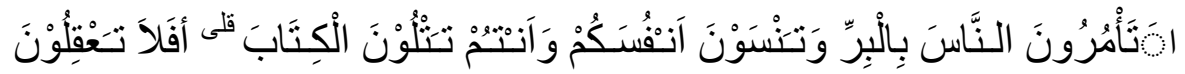

Artinya : "Mengapa kamu suruh orang lain (mengerjakan) kabaktian, sedang kamu melupakan diri (kewajiban) mu sendiri, Padahal kamu membaca al-Kitab (Taurat) ? maka tidakkah kamu berpikir? (Q.S al-Baqarah : 44) ${ }^{23}$

\footnotetext{
${ }^{22}$ Muhammad Quthb, t.th, Terj. Salman Harun "Sistem Pendidikan Islam”, Bandung : Maarif, 1993, hlm.334.

${ }^{23}$ Depag. R.I, Terjemah..., hlm. 16.
} 
Agar harapan orangtua terpenuhi dengan mengikuti apa yang diperintahkan dan diajarkannya, tentunya disamping memberikan nasehat yang baik juga ditunjang dengan teladan yang baik pula. Karena pembawaan anak mudah terpengaruh oleh kata-kata yang didengarnya dan juga tingkah aku yang sering dilihatnya dalam kehidupan sehari-hari dari pagi sampai sore hari.

Nasehat juga harus diberikan sesering mungkin kepada anak-anak masa sekolah dasar, sebab anak sudah bersosial dengan teman sebayanya. Agar apaapa yang telah diberikan dalam keluarganya tidak mudah luntur atau tepengaruh dengan lingkungan barunya.

Menurut Ulwan, dalam Penyajian atau memberikan nasehat itu ada pembagiannya, yaitu ${ }^{24}$

a. Menyeru untuk memberikan kepuasan dengan kelembutan atau penolakan.

Sebagai contohnya adalah seruan Lukman kepada anak-anaknya, agar tidak mempersekutukan Allah SWT. Q.S. Lukman (31) :13.

$$
\text { و أذ قال لقمن لابنهه وهو يعظه يـنـي لاتثرك بالله قلى إن الثرك لظلم عظيم }
$$

Artinya:"Dan (ingatlah) ketika Luqman berkata kepada anaknya, di waktu ia memberi pelajaran kepadanya: "Hai anakku, janganlah kamu mempersekutukan Allah, Sesungguhnya mempersekutukan (Allah) adalah benar-benar kezaliman yang besar." (Q.S Luqman : 13). ${ }^{25}$

b. Metode cerita dengan disertai tamtsil 'ibarat dan nasehat

Metode ini mempunyai pengaruh terhadap jiwa dan akal. Biasanya anak itu menyenangi tentang cerita-cerita. Untuk itu orang tua sebisa mungkin untuk memberikan masalah cerita yang berkaitan dengan keteladanan yang baik yang dapat menyentuh perasaannya.Sebagaimana firman-Nya dalam QS. al-A`raf (7) : 176.

$$
\text { ..فالقصص القصص لـعلهم يـفكرون -(الاعر اف:176)- }
$$

\footnotetext{
${ }^{24}$ Abdullah Nashih Ulwan, Tarbiyah...., hlm. 70.

${ }^{25}$ Depag. RI, Terjemah..., hlm. 654.
} 
Artinya: “... Maka ceritakanlah (kepada mereka) kisah-kisah itu agar mereka berpikir", 26

Terlebih di dalam Islam, banyak menawarkan kisah-kisah inspiratif baik yang bersumber dari Al-Qur'an, Hadis, maupun kisah-kisah para orang-orang saleh terdahulu.

\section{Pendidikan dengan Perhatian}

Sebagai orangtua berkewajiban untuk memenuhi kebutuhankebutuhan anaknya, baik kebutuhan jasmani ataupun kebutuhan yang berbentuk rohani. Diantara kebutuhan anak yang bersifat rohani adalah anak ingin diperhatikan dalam perkembangan dan pertumbuhannya.

Pendidikan dengan perhatian adalah mencurahkan, memperhatikan dan senantiasa mengikuti perkembangan anak dalam pembinaan akidah dan moral, persiapan spiritual dan sosial, disamping selalu bertanya tentang situasi pendidikan jasmani dan daya hasil ilmiahnya. ${ }^{27}$

Orang tua yang bijaksana tentunya mengetahui perkembanganperkembangan anaknya. Terutama ibu, karena perannya sebagai tokoh pembentuk kepribadian anak lebih dominan dibanding seorang ayah. Tiap hari waktu Ibu banyak bersama dengan anak, sehingga wajar bila kecenderungan anak lebih dekat dengan para ibunya. Untuk itu ibu diharapkan mampu berkiprah dalam mempersiapkan pertumbuhan dan perkembangan putra-putrinya.

Berdasar fungsi ibu sebagai orang tua ini yang mendasari perbedaan antara manusia dengan spesies hidup lainnya. Keunggulan dari anak turun hewan tergantung dari pejantannya, mengingat keunggulan tersebut hanya didasarkan pada fisik semata. Berbeda dengan manusia, fisik bukanlah satusatunya pertimbangan manusia dikatakan sebagai pribadi yang unggul. Justru terdapat psikis yang mampu menumbuhkan pribadi yang humanis.

Sebagaimana Rasulullah Saw. menjelaskan dalam hadis yang diriwayatkan oleh Aisyah Ra.; "Termasuk penyempurnaan iman seorang

${ }^{26}$ Ibid., hlm. 251.

${ }^{27}$ Abdullah Nashih Ulwan, Tarbiyah..., hlm. 123 
yang beriman adalah keluhuran budi pekerti dan kelemah-lembutan terhadap keluarganya". 28

Orang tua yang baik senantiasa akan mengoreksi perilaku anaknya yang tidak baik dengan perasaan kasih sayangnya, sesuai dengan perkembangan usia anaknya. Sebab pengasuhan yang baik akan menanamkan rasa optimisme, kepercayaan, dan harapan anak dalam hidupnya. ${ }^{29}$ Dalam memberi perhatian ini, hendaknya orang tua sekedar kebutuhan, tidak terlalu berlebihan dan juga tidak terlalu kurang. Namun perhatian orang tua disesuaikan dengan perkembangan dan pertumbuhan anak.

Apabila orang tua mampu bersikap penuh kasih sayang dengan memberikan perhatian yang cukup, niscaya anak-anak akan menerima pendidikan dari orang tuanya dengan penuh perhatian juga. Namun pangkal dari seluruh perhatian yang utama adalah perhatian dalam akidah.

\section{Pendidikan dengan Punishment}

Hukuman diberikan, apabila metode-metode yang lain sudah tidak dapat merubah tingkah laku anak, atau dengan kata lain cara hukuman merupakan jalan terakhir yang ditempuh oleh pendidik, apabila ada perilaku anak yang tidak sesuai dengan ajaran Islam. Sebab hukuman merupakan tindakan tegas untuk mengembalikan persoalan di tempat yang benar. ${ }^{30}$ Hukuman sesungguhnya tidaklah mutlak diberikan. Karena ada orang dengan teladan dan nasehat saja sudah cukup, tidak memerlukan hukuman. Tetapi pribadi manusia tidak sama seluruhnya. ${ }^{31}$ Sebenarnya tidak ada pendidik yang tidak sayang kepada siswanya. Demikian juga tidak ada orang tua yang merasa senang melihat penderitaan anaknya. Dengan memberikan hukuman, orang tua sebenarnya merasa kasihan terhadap anaknya yang tidak mau melaksanakan ajaran Islam. Karena salah satu

\footnotetext{
${ }^{28}$ HR. At-Tirmidzi

${ }^{29}$ Muhammad Ali al-Hasyimi, The Ideal..., hlm. 262

${ }^{30}$ Muhammad Quthb, Sistem..., hlm. 341.

${ }^{31}$ Ibid. hlm. 341
} 
fungsi dari hukuman adalah mendidik. ${ }^{32}$ Sebelum anak mengerti peraturan, ia dapat belajar bahwa tindakan tertentu benar apabila tidak menerima hukuman dan tindakan lainnya salah apabila mendapatkan suatu hukuman.

Umat manusia dapat meneladani bagaimana Allah mendidik mereka. Tarbiyah Allah Swt. terhadap umat manusia berupa memberi pahala dan sekaligus menegaskan adanya ancaman siksa. Orang tua harus mengerti bahwa seorang anak tidak boleh hanya dipuji dan dituruti keinginannya, tetapi pada suatu hari orang tua harus berani bersikap tegas dengan memberi hukuman apabila melakukan kesalahan. ${ }^{33}$

Tindakan tegas terhadap anak, bukan perkara yang mudah. Hal ini dapat dilakukan oleh orang yang memiliki keteguhan hati. Abu Tammam -sebagaimana yang dikemukakan Masyhuda al-Mawwaz- berkata: ${ }^{34}$

"Maka dia bertindak keras supaya mereka bisa dicegah. Seseorang yang teguh pada suatu saat mesti bertindak keras kepada orang yang dikasihinya."

Dalam memberikan hukuman ini diharapkan orang tua melihat ruang waktu dan tempatnya. Diantara metode memberikan hukuman kepada anak adalah : ${ }^{35}$

a. Menghukum anak dengan lemah lembut dan kasih sayang.

b. Menjaga tabiat anak yang salah.

c. Hukuman diberikan sebagai upaya perbaikan terhadap diri anak, dengan tahapan yang paling akhir dari metode-metode yang lain.

Seharusnya para orang tua sebisa mungkin menahan emosi untuk tidak memberi hukuman fisik, ketika hukuman yang berbentuk psikologis sudah mampu merubah sikap anak. Sebagaimana yang dikemukakan oleh Nashih Ulwan, hukuman bentuknya ada dua, yakni hukuman psikologis dan hukuman biologis.

Bentuk hukuman yang bersifat psikologis adalah: ${ }^{36}$

${ }^{32}$ Elizabeth B. hurlock, t.t. Terj. Med.Meitasari Tjandrasa, "Perkembangan Anak", Jakarta: Erlangga, jilid II, 1999, hlm. 87.

${ }^{33}$ Masyhuda al-Mawwaz, Mengantar Anak..., hlm. 71

${ }^{34} \mathrm{Ibid} .$, hlm. 71

${ }^{35}$ Abdullah Nashih Ulwan, Tarbiyah..., hlm. 155.

${ }^{36}$ Ibid., hlm. 159. 
a. Menunjukkan kesalahan dengan pengarahan.

b. Menunjukkan kesalahan dengan memberikan isyarat.

c. Menunjukkan kesalahan dengan kecaman.

Hukuman bentuk psikologis ini diberikan kepada anak di bawah umur 10 tahun. Apabila hukuman psikologis tidak mampu merubah perilaku anak, maka hukuman biologislah yang dijatuhkan tatkala anak sampai umur 10 tahun tidak ada perubahan pada sikapnya. Hal ini dilakukan supaya anak jera dan tidak meneruskan perilakunya yang buruk.

Masa anak-anak sangat potensial untuk dididik dalam lingkungan keluarga. Praktek Living Sunnah yang sederhana dapat diterapkan, sebagai contoh mengoptimalkan waktu 'Isya'ain (antara Maghrib dan Isya') sebagai "Waktu keluarga" digunakan untuk pembinaan terhadap anak melalui melatih mengaji Al-Qur'an dan belajar materi sekolah. Orangtua harus mempunyai ketegasan dalam membuat aturan dan mengatur jadwal belajar anak semisal antara seusai Maghrib sampai jam 20.00 WIB. Tentunya orang tua harus konsekuen, ketika anak disuruh untuk belajar, orang tua mendampingi di sampingnya atau paling tidak menemani belajar dengan melakukan aktivitas lain. Tidak dibenarkan orang tua menyuruh anaknya belajar, sementara dirinya asyik nonton Televisi atau tidur. Contoh seperti ini tidak mencerminkan metode keteladanan yang telah disinggung sebelumnya.

Anak adalah aset orang tuanya dan anugerah Allah Swt. yang memberikan kesempatan kepada ayah dan ibunya untuk tetap bisa memperoleh tambahan pahala meski keduanya meninggal dunia. Anak keturunan yang saleh dan selalu mendoakan orang tua adalah investasi orang tua yang didapatkan setelah meninggal. Sebagaimana dalam hadis yang sangat masyhur disebutkan; "Ketika anak Adam meninggal dunia, maka terputuslah amalnya kecuali tiga perkara; sedekah Jariyah, ilmu yang bermanfaat, dna anak saleh yang selalu mendoakannya., ${ }^{37}$

\section{Kesimpulan}

${ }^{37}$ HR. Muslim 
Orangtua merupakan pemegang amanah dalam memberikan kebutuhan biologis, merawat, dan memberikan pendidikan. Lingkungan keluarga punya peranan penting dalam pendidikan anak dititikberatkan pada curahan kasih sayang yang mengiringi proses pendidikan. Dimensi praktis pendidikan Islam memerlukan pengawasan yang optimal yang dapat diberikan oleh orang tua dalam lingkungan kelurga. Prinsip yang harus diterapkan orng tua dalam pendidikan anak adalah tidak terlalu keras dan tidak terlalu lembut terhadap anak.

Keluarga Islami melalui implementasi Living Sunnah dan dioptimalkan dengan beberapa metode, seperti; keteladanan, Pembiasaan, Hukuman, dan Nasehat.

Metode Pembiasaan dapat dilakukan oleh keluarga Islami melalui perintah menutup aurat, salat berjamaah 5 waktu, dan sebagainya. Implementasi metode pembiasaan, metode nasehat harus terintegrasi dengan metode keteladanan.

\section{DAFTAR PUSTAKA}

'Ali Quthb Muhammad. 1993. Auladuna fi-Dlaw-it Tarbiyyatil Islamiyah, Terj. Bahrun Abu Bakar Ihsan, "Sang Anak dalam Naungan Pendidikan Islam”, cet. ke-2, Bandung : Diponegoro.

Al-Mawwaz, Masyhuda. 2010. Mengantar Anak ke Surga, Surabaya: Edutama Mulia.

'Isawi, Abdurrahman. Anak dalam Keluarga, 1994. Jakarta : Studia Press.

Abu Ghuddah, Abd al-Fattah. T.th., Ar-Rasul al-Mu'alim wa asaliibihi fi atTa'lim, Maktabah Al-Manba'.

Ali al-Hasyimi, Muhammad. 2000. The Ideal Muslimah the True Islamic Personality of The Muslim Woman as Defined in The Qur'an and sunnah, Terj. Fungky Kusnaedi Timur, "Muslimah Ideal pribadi Islami dalam alQur'an dan as-Sunnah", Yogyakarta : Mitra Pustaka.

At-Tirmidzi, Muhammad bin Isa, t.th., Sunan At-Tirmidzi, Juz ke-4, Lebanon : Dar al-Kutub al-Ilmiah.

Binti Mubarok, Haya.1998. Mausu'ah al-Mar'atul Muslimah, terj. Amir Hamzah Fachrudin, "Ensiklopedi Wanita Muslimah", cet. ke-4, Jakarta : Darul Falah. 
Elizabeth B. Hurloc. 1999. Perkembangan Anak, Terj. Med.Meitasari Tjandrasa, jilid ke-2, Jakarta: Erlangga.

Mushoffa, Aziz, dkk., 2001. Sepasang Burung dan Nabi Sulaiman, Yogyakarta: Mitra Pustaka.

Muslim bin Hajjaj, t. th., Shahih Muslim, juz ke-4, Lebanon : Dar al-Kutub alIlmiah.

Quthb, Muhammad. 1993. Sistem Pendidikan Islam, Terj. Salman Harun, Bandung: Ma-arif. 